\title{
Country Branding and its effect on the consumer in the global market
}

\section{Gestión de la Marca País y sus efectos en el consumidor en un mercado globalizado}

\author{
KeRry KILDUfF $^{1}$ \\ Julia M. NúÑ̃z TABALEs ${ }^{1}$ \\ Universidad de Córdoba (España)
}

Recibido el 6 de mayo de 2015, aceptado el 2 de febrero de 2016

Publicado online el 4 de mayo de 2016

$\mathrm{N}^{\mathrm{o}}$ de clasificación JEL: F10, M31

DOI: $10.5295 / \mathrm{cdg} .150543 \mathrm{kk}$

\begin{abstract}
:
Country Branding - a relatively new type of marketing and public diplomacy-is a developing field and a tool that governments use to promote their goods and services and to enhance awareness about their country, promote tourism, increase trade and attract foreign direct investment (FDI) and talent. A Country Brand is more than a sum of its products. The purpose of this literature review is to investigate the key components of international and intercultural transactions and to focus on how these influence the Nation Brand. In the global marketplace, where products and services from different countries are competing for market share, it is important to understand how a product's place of origin contributes its overall image, and how consumers relate to the foreign product. By identifying the consumer it is possible to gain an understanding of the cultural influences that determine the consumers' relation to the product, service, or Nation Brand.
\end{abstract}

Likewise, this paper relates previous studies in the fields of country-of-origin (COO) and consumer studies as influential factors the evolution of Country Branding. By gaining a clear idea of the relationship between these three fields -COO, consumer and Country Branding-, scholars and professionals can assess the influence that a product's country-of-origin has on its audience, and create country brands that effectively define the product and reach target consumers.

\section{Keywords:}

Country Branding, country-of-origin (COO), consumer, foreign goods.

\section{Resumen:}

La Gestión de la Marca País -rama de estudio relativamente nueva y en desarrollo- es un instrumento que los gobiernos utilizan para promover sus bienes y servicios, para mejorar el conocimiento de cada país, promover el turismo, incrementar el comercio y atraer inversión extranjera directa (IED) y talento. Una Marca País es más que la suma de sus productos. El objetivo de esta revisión literaria es investigar los componentes claves en las transacciones internacionales e interculturales e identificar su influencia en la formación de la Marca País.

1 Facultad de Derecho y Ciencias Económicas y Empresariales, Puerta Nueva s/n, 14071 Córdoba (España). kkilduff@ucla.edu; es2nutaj@uco.es 
En el mercado global, donde los productos y servicios de países diferentes compiten por la cuota de mercado, es importante entender el modo en que el lugar de origen de un producto contribuye a su imagen de conjunto, así como la forma en que los consumidores se relacionan con el producto extranjero. Identificando al consumidor se puede entender las influencias culturales que determinan la relación de los consumidores con el producto, el servicio o la Marca País.

Así pues, en este trabajo se relacionan estudios anteriores en los campos de país de origen (COO) y los relativos al consumidor como factores decisivos en la evolución del concepto Marca País. Al obtener una idea clara de la relación entre estos tres campos -COO, consumidor y Marca País-, los académicos y profesionales podremos: valorar la influencia que el país de origen de un producto tiene sobre su público, crear una Marca País que defina sus productos y llegar exitosamente al consumidor objetivo.

\section{Palabras clave:}

Gestión de Marca País, país de origen, consumidor, bienes extranjeros. 


\section{INTRODUCTION}

Place branding is a tool that has been increasingly used by governments in the past two decades to enhance awareness about their country, promote tourism, increase trade and attract foreign direct investment (FDI) and talent. The concept of place branding arose in the early 1990s (Kotler et al. 1993; Anholt 1998) and has since then been studied, discussed and developed by scholars, private companies, and governments. Place branding can be employed as locally as a neighborhood or a city, or as broadly as a region or a country. In this paper, the focus is on place branding at the national level. Though it is a complex and multi-faceted assignment, managing a nation's image is crucial for a country to compete commercially, politically, socially and culturally in the global marketplace. It is a tool that helps to define an image in the minds of consumers, enhances the perception of those who have little or no personal connection with a country, as well as redefines stereotypes that may be broad, misleading or outdated. If the national image of country is clearly and concisely presented to an audience, it invites the consumer to create relationship with the location.

In promoting trade and investments, it is important that countries have clear, succinct images, since a strong and positive brand image constantly accompanies citizens and companies: "their nation brand goes before them like a calling card, opening doors, creating trust, generating respect and raising the expectation of quality, competence and integrity" (Anholt 2008, p. 207). If a nation does not brand itself internationally, it gives the opportunity for others to define them (Van Ham 2001), which makes re-branding the country's reality even more difficult. This idea is demonstrated in the 2006 mockumentary "Borat: Cultural Learnings of America for Make Benefit Glorious Nation of Kazakhstan" to see how one movie affected Kazakhstan's reputation abroad (Fullerton et al. 2008; Van Ham 2008; Stock 2009b).

The purpose of this literature review is to investigate the key components of international and intercultural transactions and to focus on how these influence the nation brand. In the global marketplace, where products and services from different countries are competing for market share, it is important to understand how a product's place of origin contributes its overall image, and how consumers relate to the foreign product. An examination of how products and services relate to their country-of-origin (COO) will be carried out. How does country-of-origin affect the image of the product offered? How is national identity transmitted through a product or service? By gaining an understanding of the product, the shift is then shifted our focus to the consumer: how does the "made-in" label on a product, an informational cue, affect consumers' responses to products or services? Is this information beneficial to the product, and to creating an idea of the country of origin? A nation brand is more than a sum of its products. By gaining an understanding of the effects of COO, it's possible to learn how the provenance of a product or service influences consumers' opinions and thus contributes to the foreign perception of a nation brand.

This review is not intended to be an all-inclusive review of the literature regarding country-of-origin, consumer behavior and nation branding. This review seeks to cover the most relevant investigations, issues and themes and the main topics in order to gain insight how nation brands are formed, how they can be managed, and how countries can use these ideas to develop their place brand. 


\section{HOW THE COUNTRY-OF-ORIGIN (COO) AFFECTS THE PRODUCT}

The concept of country-of-origin is attributed to Robert Schooler (1965), who conducted a study among Guatemalan students. When presented with a cloth product whose label identified the country that the product came from (either Mexico, Costa Rica, El Salvador or Guatemala), Schooler found that the Guatemalan respondents preferred products from Mexico and Guatemala to those from Costa Rica and El Salvador, thus showing that a hierarchy of product preferences exists based on country of origin. In reality, all four products had been produced in Guatemala. The study, though groundbreaking, has been deemed simplistic, since the study does not examine to what extent the country-of-origin effect influences consumers' decisions.

In a subsequent study, Schooler (1971) studied foreign products in the United States. He found there were significant biases towards and against goods from foreign countries, and that the biases varied when stratified. For example, he found that consumers, depending on their level of education, were more or less accepting of foreign products. The higher the level of education, the more positively consumers valued the products. This conclusion has been confirmed by various other studies (Anderson and Cunningham 1972; Dornoff et al. 1974; Heslop and Wall 1985). Gender also played a role in the country-of-origin effect: women were more likely to positively evaluate foreign products than men. Another finding in Schooler's study was that age also made a difference, as younger consumers were more open to foreign products than older consumers.

Country-of-origin perceptions have been shown to change over time. A study evaluating the attitudes of Japanese businessmen regarding products from five countries in 1967 and subsequently in 1975 concluded that over the eight-year period, the businessmen's opinions of the products were modified (Nagashima 1977). This study gives basis for the field of country image management, which aims to create positive attitudes or re-shape prior country images that, in turn, stimulate tourism, exports, and FDI. This study was the first to use a seven-point semantic differential scale, hailing results that more concisely represent the participant's attitudes.

By compiling a literature review of country-of-origin studies to date, it facilitates outlining the findings and shortfalls of these works to encourage further study of the field (Bilkey and Nes 1982). In summarizing remaining issues such as what influences countryof-origin biases and whether these biases are superficial or rooted in a society, Bilkey and Nes encourage product-country image to become a growth industry and not a stagnant field of research. Through reviewing previous studies, the authors confirmed that $\mathrm{COO}$ influences consumer perceptions of the products, but could not determine how much of an influence this cue accounts for. This study also raises the question of whether the COO bias stems from the foreign country's political, social, and economic development, or if the $\mathrm{COO}$ bias resides within the consumer and is influenced by attitudes towards nationalism, ethnocentrism, and previous experiences with imports. The latter part of this issue will be explored in the second part of this literature review.

The influence of the COO effect on consumers was challenged by the results of several studies. In one study, subjects were asked to assess Japanese, American, and German made cars based on thirteen features: price, handling, horsepower, acceleration, gas mileage, safety, driving comfort, passenger comfort, reliability, durability, workmanship, styling 
and color selection (Johansson et al. 1985). This study was the first to use the multi-cue approach; by adding cues other than $\mathrm{COO}$, the study attempts to simulate a real-life consumer situation. The study found that country-of-origin effects were less significant than had previously been accepted and that other contributing factors influence the consumer's decision-making process. One source of criticism of this study, however, is that respondents are asked to rate the product attributes in an artificial environment - they are not actually interested consumers making informed decisions about buying a car, rather are only deciding based on verbal cues rather than a tangible product (Bilkey and Nes 1982).

A subsequent study distinguished between country of design (COD) and country of manufacture (COM). With cars, it was found that COD was a significant indicator in perceived quality (Hamzaoui and Merunka 2006).

The halo effect and the summary concept are terms from other fields of research applied to the $\mathrm{COO}$ effect to describe the relationship between product and country, described in a study comparing American, Japanese and South Korean-made televisions and cars (Han 1989). The products were rated on a seven-point scale. The results of this study revealed that consumers employ either a halo effect or a summary construct when making decisions about products. The halo effect occurs when consumers use general information they know about a country to evaluate products that they have little knowledge about. Consumers use the summary construct when they are familiar with a country's products and in turn develop associations and beliefs about the country based on their evaluation of the product's attributes.

The halo effect was examined further by Han when he hypothesized that country image is conceptualized as a consumer halo (Han 1990). By asking consumers via a multi-cue approach their opinions regarding technical advancement, prestige value, workmanship, price and serviceability of Japanese, American and South Korean cars and TVs, Han concluded that consumers were more likely to buy a product from a country based on how they perceived the economic, political and cultural characteristics of the country the product came from. This tendency is even more likely to occur when the product's country is economically, politically and culturally similar to the consumer's own country.

The conclusions of this study can be directly associated to the work of nation branders, who attempt to manage the image of a country in order to improve the opinions of consumers. When consumers recur to the halo effect to evaluate countries, it can have a real influence on aspects of the economy such as exports and foreign direct investment, not to mention perceptions of the culture exports and political actions. When attempting to brand a nation, governments, academics and marketing firms must act to manage the halo image of the country and either confront negative perceptions, familiarize distant audiences with the country, or reinforce positive images.

Every place (country, region, city, neighborhood, etc) has an image that develops in the minds of consumers by means of media, education, travel, immigrants, purchase of exported goods, etc. (Papadopoulos and Heslop 1993). The term Product-Country Image is used to describe the perception that consumers have about the products and their countryof-origin. Some products make special reference to their COO in their name or marketing strategy. For example, Spanair or American Airlines use their countries in the company names; Gucci and Ferrari are associated with Italy because of the brand names are derived from words and names in Italian. These cues link the product to a country and therefo- 
re draw upon the country image to bestow unique characteristics upon the product. This study also identifies the idea of countries promoting their products as well as themselves as destinations for tourism and FDI, paving the way for future studies (Wee et al. 1993; Papadopoulos et al. 1997).

The concept "brand origin" should be distinguished from country-of-origin or productcountry image. Brand origin is defined as "the place, region or country to which the brand is perceived to belong by its target consumers" (Thakor and Kohli 1996, p. 32). The Spanish brand Massimo Dutti, part of the Inditex family, embodies the concept of brand origin. Consumers perceive the brand as Italian because of its name and therefore associate it with characteristics attributed to Italian fashion. The perception of the brand would perhaps be different if the brand had a Spanish name to match its real country-of-origin. Furthermore, the authors distinguish between brand origin and where the product is actually made. Massimo Dutti products are not produced in Italy or even Spain, in some cases.

Country images are not stagnant (Nagashima 1977; Lampert and Jaffe 1998). Figure 1 demonstrates Lampert and Jaffe's concept of a country's product image life cycle.

Figure 1

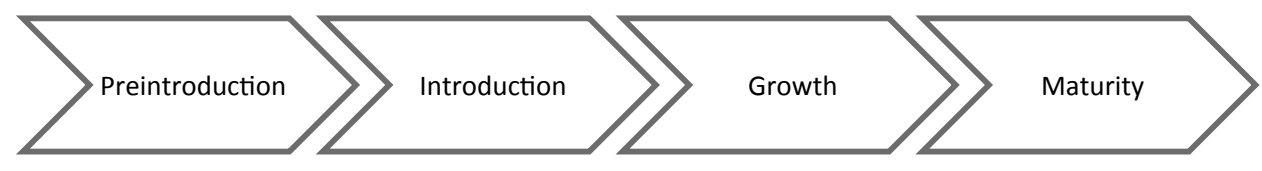

Source: Own elaboration; adapted from Lampert and Jaffe (1998).

Each market will have different reactions to COO cues, an idea that must be taken into account when promoting a product and its origin abroad. In the case of Colombia, studies showed that Colombian consumers, when faced with unfamiliar products, will not depend on the country of origin cue in valuing the product (Concha Velásquez et al. 2011). Consumers who have had first-hand experience with the product will be less influenced by COO than those who haven't. This study, however, only tests one consumer product, beer, and does not look into how the market would receive other products of mass consumption which may be of more (or less) importance to the consumers in their everyday lives.

On the other hand, instead of observing how a country's image influences the perception of a brand, White proposes that the influence and perception of a brand can have positive effects on the image of a country (White 2012). This study demonstrated a brand international that it is positively valued (like Skype technological program or the energy drink Red Bull) helps to improve the perception of unknown or small countries when consumers find out about the country of origin of the products (in the case of the products listed earlier, Estonia and Austria). Furthermore, the more familiar consumers are with a product, the more they associate it with a country or countries. The same occurs in reverse: the more familiar consumers are with a country, the more they know about the products available from this origin (Usunier and Cestre 2007). 
Table 1

Main contributions about the influence of the $\mathrm{COO}$ on the product (chronological order)

\begin{tabular}{|c|c|c|c|c|}
\hline Author & Year & $\begin{array}{l}\text { Country whe- } \\
\text { re took place }\end{array}$ & $\begin{array}{c}\text { Country (s) or area (s) } \\
\text { analyzed (s) }\end{array}$ & Type of study \\
\hline Schooler & 1965 & Guatemala & $\begin{array}{c}\text { Guatemala, Mexico, Costa } \\
\text { Rica, El Salvador }\end{array}$ & Quantitative \\
\hline Schooler & 1971 & USA & $\begin{array}{l}\text { USA, West Germany, Cze- } \\
\text { choslovakia, India, Chile, } \\
\text { Nigeria, North America, } \\
\text { Western Europe, Eastern } \\
\text { Europe, Asia, Latin Ameri- } \\
\text { ca, Africa }\end{array}$ & Quantitative \\
\hline Nagashima & 1977 & Japan & $\begin{array}{l}\text { USA, Germany, United } \\
\text { Kingdom, France }\end{array}$ & Quantitative \\
\hline Bilkey and Nes & 1982 & N/A* & N/A* & Qualitative \\
\hline Johansson et al. & 1985 & USA, Japan & Germany, USA., Japan & Quantitative \\
\hline Han & 1989 & USA & USA, Japan, Korea & Quantitative \\
\hline $\begin{array}{l}\text { Papadopoulous and } \\
\text { Heslop }\end{array}$ & 1993 & N/A & N/A & Qualitative \\
\hline Thakor & 1996 & Canada & N/A & Qualitative \\
\hline Lampert and Jaffe & 1998 & Israel & N/A & Qualitative \\
\hline $\begin{array}{c}\text { Hamzaoui and } \\
\text { Merunka }\end{array}$ & 2006 & Tunisia & $\begin{array}{c}\text { Japan, Germany, Korea, } \\
\text { Italy, Taiwan, France }\end{array}$ & Quantitative \\
\hline Pappu et al. & 2007 & Australia & Japan, Malaysia, China & Quantitative \\
\hline Usunier and Cestre & 2007 & $\begin{array}{l}\text { China, Ger- } \\
\text { many, Mexico } \\
\text { and U.S. }\end{array}$ & $\begin{array}{c}\text { Germany, Belgium, Brazil, } \\
\text { China, Korea, France, Great } \\
\text { Britain, India, Italy, Japan, } \\
\text { Spain, the Netherlands, } \\
\text { Poland, Russia, Sweden, } \\
\text { Switzerland, Tunisia, U.S. } \\
\text { and } 49 \text { other countries that } \\
\text { were not considered due to } \\
\text { low association scores }\end{array}$ & Quantitative \\
\hline $\begin{array}{l}\text { Roth and Diaman- } \\
\text { topoulos }\end{array}$ & 2009 & N/A & N/A & Qualitative \\
\hline White & 2012 & USA & Austria, Sweden, Estonia & Quantitative \\
\hline
\end{tabular}

* The most qualitative studies do not include information specific to a country, hence "not applicable" (N/A) in the corresponding cells.

Source: Own elaboration.

Table 1 contains a summary of the main contributions (in chronological order) on influence of the country of origin on the product, detailing the author, year, country where it was studied, the country(s) or area(s) analyzed, as well as whether a quantitative or qualitative study was carried out. 


\section{THE CONSUMER: REACTIONS TO FOREIGN GOODS AND SERVICES}

The influence of the country-of-origin effect on a product is one important variable, but in this section the focus is on the consumer: the person who interprets the product's country-of-origin information and decides whether or not to buy the product. The consumer may possess preconceived ideas about the quality of products from certain countries (Chasin and Jaffe 1979); they may have opinions about their duty to their nation to buy local products (Bruning 1997), or they may have the tendency to buy products that are produced in countries that are economically, socially and politically similar to their own (Han 1989). All of these factors contribute to a reaction consumers may have when faced with foreign products and services, and it is important to identify these issues in order to overcome barriers and create an effective nation brand. Furthermore, consumer reactions vary from country to country, and it is essential to recognize these differences between consumers.

\subsection{National characteristics and national identity}

The consumers' perception of a product significantly changes (for the better and for the worse) when they are told the country-of-origin of the product (Bannister and Saunders 1978). If the COO can influence consumers' perception of a product or service, then improving the image portrayed through the $\mathrm{COO}$ should be positioned to increase the number of foreign consumers. This study first introduced the idea that countries have images (like brands) in the field of academic research.

When comparing a country's image in different sectors, the image is not consistent (Jaffe and Nebenzahl 2001). For example, French wine may be highly valued by consumers, but French technology may not share the same prestigious image. Consumer ethnocentrism, therefore, is likely to also vary depending on the product. Perhaps a Taiwanese consumer would prefer buying local, Taiwanese technology, however they would choose French wine over wine from their country.

Furthermore, consumers form their country image perceptions based on more than simply purchasing that country's products (Jaffe and Nebenzahl 2001). This is a step towards broadening the field of nation brand research: country images are formed not only by exports; aspects such as tourism and media coverage also affect nation brand images. In addition, Jaffe and Nebenzahl present a widely-accepted objective of nation branding: "to create a clear, simple, differentiating idea built around emotional qualities which can be symbolized both verbally and visually and understood by diverse audiences in a variety of situations. To work effectively, nation branding must embrace political, cultural, business and sport activities" (Jaffe and Nebenzahl 2001, cited in Fan 2005, p. 3). This broad statement has motivated governments to design and implement wide-ranging country brand campaigns.

The notion of branding a country is validated by the idea that a nation's image influences perceptions of products (O'Shaughnessy and O'Shaughnessy 2000). Consumers perceive foreign products in two ways: reputational capital is a belief-driven factor for consumers, where the buyer believes that the nation is (or isn't) able to create a product that stands up to the standards they seek from the product. Alternatively, an imagery-centric 
approach relies on a positive association with a nation brand which affects consumer purchases. Since a nation's image can be diverse and in some cases contradictory, the product that aims to exploit its nation brand should concentrate on the adequate, positive national characteristics for the product and for the target market. The authors posed the question of whether or not this image can be exploited to promote exports.

\subsection{Consumer ethnocentrism}

A study about opinion of American industrial buyer's opinions of manufactured goods from Eastern European countries showed that American buyers perceived the products from Eastern European countries to be inferior to those from the United States (Chasin and Jaffe 1979). This study was a precursor to the idea of consumer ethnocentrism: the bias that a consumer has towards products from their home country. This study inspired Shimp and Sharma's subsequent 1987 study, and Chasin and Jaffe's study identifies an important goal of nation branding: overcoming buyer's tendency to choose national products over international.

Consumer ethnocentrism is defined by Shimp and Sharma as "beliefs held by...consumers about the appropriateness, indeed morality, of purchasing foreign-made products" (Shimp and Sharma 1987, p. 280), and was first systematically measured using the CETSCALE, developed in the same study. Though this study is a starting point for research into how consumers compare foreign-made and domestic products, the investigation calls for more research into how and when these tendencies are instilled in consumers.

Subsequent studies have shown that brand origin recognition accuracy is quite low - the country of origin is for the most part insignificant in consumer's brand choice (Samiee et al. 2005). Both studies allow place branders to identify regional tendencies and work to develop strategies that are aimed at the biases of consumers in each region.

Various factors influence consumers' ethnocentric tendency to buy or reject imported products. Some of the factors that affect the consumer's opinion are their acceptance of other cultures, their perception of patriotism, conservatism and individualism (Sharma et al. 1995). Consumers that exhibit qualities such as openness to foreign cultures and individualism reveal weaker ethnocentric tendencies, whereas patriotism, conservatism and collectivism describe consumers with stronger ethnocentric tendencies. Demographic variables also play a part in consumer ethnocentrism (Han 1989; Schooler 1971). Higher income and level of education correlate to lower ethnocentric tendencies, suggesting that these consumers are more likely to buy foreign products (Sharma et al.1995). Furthermore, the consumers' perceived need for the product moderates their ethnocentric tendencies: if the product is foreign but is considered a necessity, the consumer will display only moderate ethnocentric tendencies. Similarly, the extent to which the consumer perceives that buying this product poses a threat him personally and/or to the domestic economy also influences a consumer's ethnocentric bias.

$\mathrm{COO}$ bias also seems to affect consumer trust when contemplating high-risk services, such as life insurance (Michaelis et al. 2008); in the same way COO does play a role in "low-involvement" products (bread, coffee), however when other clues are introduced, such as price or brand, the role of COO diminishes (Ahmed et al. 2004). The consumer 
prejudices highlighted in this study are essential to keep in mind when promoting a nation brand abroad.

The influence of national loyalty varies depending on the society in question. In a study examining Canadians' preference for airline carriers (Bruning 1997), price was found to be the deciding factor for consumers when choosing between domestic and international carriers. The second most important factor was country-of-origin. North Americans' consumers show that individual benefits (a lower price) win over the sense of belonging to a group (national loyalty). Consumers in India, despite showing nationalistic and ethnocentristic tendencies, value the quality of foreign brands, and in turn regarded foreign brands with higher status local brands (Kinra 2006). It is important that marketers understand where consumers place the most value in consuming a product.

In consumer studies, there is an important emphasis on the difference between consumer ethnocentrism and international animosity (Klein 2002). Whereas the former involves choosing between a foreign and a domestic product, the latter only refers to biases for or against goods from a specific country, not foreign countries as a whole. Unlike the countryof-origin concept, animosity does not simply influence the consumers' judgment of the product's attributes; instead it affects the consumer's willingness to buy the product. This study is significant because it highlights the difference between a country's receptiveness to foreign products and a country's hostility towards specific countries. Nation branding research frequently points to the differences between nation brand perceptions from one country to another (O’Shaughnessy and O’Shaughnessy 2000; Fan 2005; Stock 2009a), and it is important to keep in mind the individual relationship that exists between two countries when valuing the consumers' reactions to a nation brand.

There are irregularities in the traits of consumer ethnocentrism (Balabanis and Diamantopoulos 2004). To begin, consumer ethnocentrism is not a focal point in all product categories. In some situations, consumers disregard COO information and prefer foreign products to national products. Furthermore, foreign companies cannot assume that if their country's products from one sector sell well (or poorly) abroad, that products of another sector will be as widely accepted (or rejected) as those from another. In this study, British consumers preferred German cars to American, French, Italian and Japanese, but not German television sets. This inconsistency in consumer ethnocentrism provides a starting point for nation branding: if a country can create a broad, positive nation brand image, it could help improve product images in each sector.

Includes a summary in Table 2 of the major studies that have analyzed the reactions of consumers to foreign products, including the author (s) of study, the date of completion, the country where took place, the tested areas and the distinction between quantitative and qualitative study. 
Table 2

Main contributions about the perceptions of consumers (chronological order)

\begin{tabular}{|c|c|c|c|c|}
\hline Author & Year & $\begin{array}{c}\text { Country where } \\
\text { took place }\end{array}$ & $\begin{array}{c}\text { Country(s) or area(s) } \\
\text { analyzed }\end{array}$ & Type of study \\
\hline Bannister and Saunders & 1978 & United Kingdom & $\begin{array}{c}\text { Western Germany, } \\
\text { USA, France, Italia, Ja- } \\
\text { pan, United Kingdom, } \\
\text { Soviet Union }\end{array}$ & Qualitative \\
\hline Chasin and Jaffe & 1979 & USA & $\begin{array}{c}\text { Poland, Hungary, } \\
\text { Soviet Union, Austria, } \\
\text { Japan, USA }\end{array}$ & Quantitative \\
\hline Shimp and Sharma & 1987 & USA & USA & Quantitative \\
\hline Roth and Romeo & 1992 & $\begin{array}{c}\text { Ireland, Mexico, } \\
\text { USA }\end{array}$ & \begin{tabular}{|c|} 
Germany, Japan, \\
USA, France, United \\
Kingdom, Korea, \\
Ireland, Spain, Mexico, \\
Hungary \\
\end{tabular} & Quantitative \\
\hline Shimp, Sharma, Shin & 1995 & Korea & Korea & Quantitative \\
\hline Bruning & 1997 & Canada & Canada, USA, Mexico & Quantitative \\
\hline Michaelis et al. & 1998 & Poland & Poland, Germany & Quantitative \\
\hline $\begin{array}{l}\text { O'Shaughnessy and } \\
\text { O'Shaughnessy }\end{array}$ & 2000 & N/A & N/A & Qualitative \\
\hline Jaffe and Nebenzahl & 2001 & N/A & N/A & Qualitative \\
\hline Klein & 2002 & USA & $\begin{array}{c}\text { Japan, South Korea, } \\
\text { USA }\end{array}$ & Quantitative \\
\hline Ahmed, et al. & 2004 & Singapore & $\begin{array}{l}\text { France, Singapore, } \\
\text { Indonesia, Malaysia }\end{array}$ & Quantitative \\
\hline $\begin{array}{l}\text { Balabanis and Diaman- } \\
\text { topoulos }\end{array}$ & 2004 & United Kingdom & $\begin{array}{l}\text { United Kingdom, } \\
\text { USA, France, Ger- } \\
\text { many, Japan, Italia }\end{array}$ & Quantitative \\
\hline Kinra & 2006 & India & N/A & Quantitative \\
\hline $\begin{array}{l}\text { Samiee, Shimp and } \\
\text { Sharma }\end{array}$ & 2007 & USA & \begin{tabular}{|c|} 
England, France, \\
Germany, Italy, Japan, \\
Switzerland, USA \\
\end{tabular} & Quantitative \\
\hline
\end{tabular}

* The most qualitative studies do not include information specific to a country, hence "not applicable" (N/A) in the corresponding cells.

Source: Own elaboration.

\section{NATION BRANDING}

Country-of-origin research proves and explores how a product is affected and defined by its place of origin, and what the nature of this definition is. Consumer behavior can be 
understood in terms of consumer ethnocentrism and the demographic variables that influence this bias, although irregularities in these prejudices should be noted. Both of these fields of research, however, fall short when it comes to providing a holistic perspective of the cultural, political, and historical dimensions of the countries that are the focus of these studies. Nation branding combines a variety of fields of research to define a complete picture of a country, its background, people, beliefs, traditions, politics, economy, and aspirations for the future, which in turn can be used to help sell the products and services of a country.

\subsection{Marketing Places}

Place Marketing is not simply a country promotion strategy: "marketing provides a more comprehensive problem-solving framework, of which promotion is only a small part" (Kotler et al. 1993, p.16). By elaborating a comprehensive framework that invites public and private collaboration as well as the commitment of citizens, employees and businesses in order to market a place, place marketing is differentiated from tourism promotion. In Figure 2, the constituents of place marketing are stratified: target markets classify customers in order to organize marketing strategies. Marketing factors are the unique, differentiating characteristics of the location, and the planning group is those responsible for managing and enacting the place marketing strategy: the local and regional government may be in charge of strategy, but without the participation and support of the community, a place brand can't succeed. The tasks of an effective place brand include understanding the needs of the target markets and the planning group, understanding the place, developing a realistic image to promote and creating a plan to enact it, and evaluating the plan's progress. Kotler et al. (1993) affirm that places, their people, culture, heritage, infrastructure and quality of life are products whose identity can be used as a tool for selling goods, services and tourism. This simplification of a country as a mere product to be marketed has been hotly debated in place branding literature, however the idea of marketing places has become an important task of many governments.

The correlation between companies' marketing strategies and nations' increasing need to market themselves to their citizens and to the world sparked fierce debate within the field (Olins 1999). A brand, whether it is a nation or a company, must have a clear, cohesive and unified image so that its audience can be aware of, identify with and take part in the direction in which the country (or company) is going. By managing its identity, a nation also manages its loyalties and its reputation (both internally and externally), which are key aspects in being able to sell a nation's products services. Olins' ideas were challenged by other academics, especially the notion that nation branding's goal is to remold national identities and criticism of the term "brand", which trivializes a nation's character, history and culture to a product (Girard 1999). In his defense, Olins uses a historical approach to demonstrate that nations have always branded (and re-branded) themselves, more than ever in the past two centuries where empires, dictatorships, monarchies and former colonies have employed nationalistic techniques (flags, national anthems, national myths, etc.) to brand their nation as a modern state (Olins 2001). Countries, like products, have a brand that differentiates it from their competition, and Olins defends the usage of "branding", since the techniques employed for the two are similar. 
Figure 2

Levels of Place Branding

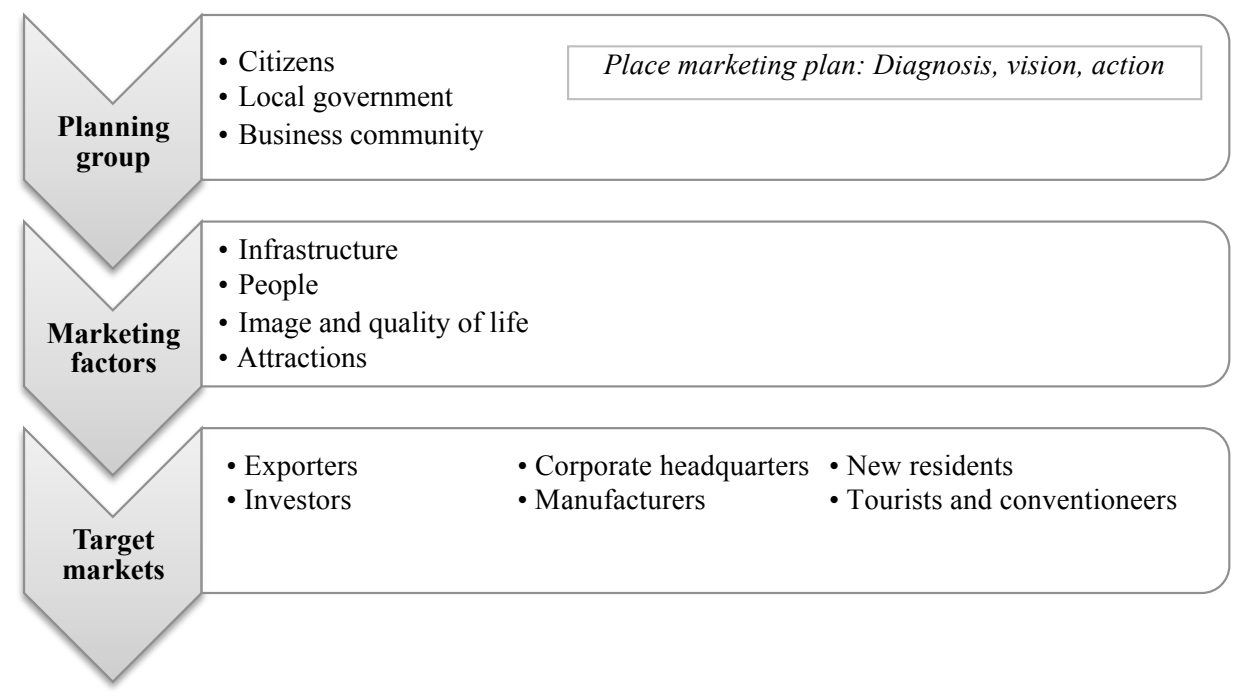

Source: Kotler et al. (1.993, p.19).

Figure 3

Miro’́s Sun

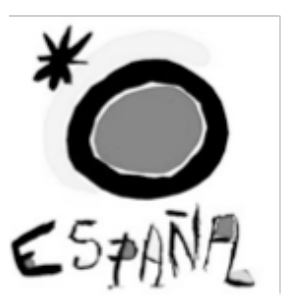

Source: Turespaña.

Spain is used as an example of a successful attempt by a country to reposition itself on the international stage (Gilmore 2002). Gilmore points to the uniformity and omnipresence of the Brand Spain's logo (Figure 3: Joan Miró's sun), the globalization of Spanish companies, and brand ambassadors, which all form part of a coordinated effort of the Spanish government, individuals, and corporations to redefine Spain as a modern and dynamic young democracy, and not the isolated, impoverished country of Francisco Franco's 36-year dictatorship. Each 
sector promoted through the Spain Brand is identified by Spain's logo of the sun, which can use concepts like the halo effect to adopt a positive association (tourism in Spain, the 1992 Barcelona Olympics, where the logo debuted) to products and services exported by Spain. The experience and success of Spain can be adopted by other, younger or undefined countries who need to differentiate themselves in order to avoid being positioned by others, or defined by negative stereotypes. Gilmore also underlines the importance of marketing that truthfully defines and captures the essence of the nation and its values; not a fabrication of what the nation hopes to become. The image of a country needs to represent the people of the nation and how they see themselves; otherwise they won't feel connected to the brand and cannot act to embody the image the nation brand promotes. Gilmore presents a framework for nation branding based on "the spirit of the people" (Gilmore 2002, p. 286) that is aimed at different target audiences (retirees, visitors, students, current and potential residents, investors, and media) but which all must resonate under one, truthful "umbrella brand". Countries must draw upon their specific advantages to promote themselves as a unique place for investment, travel from which to buy goods, and as a place to live; however differentiation is not enough: consumers must also prefer the country to others at the moment they decide to consume products or experiences from the country.

\subsection{Constructing country images}

A country image is defined by its "geography, history, proclamations, art and music, famous citizens and other features" (Kotler and Gertner 2002, p. 251). These images are subjective, are generally stereotypes, and can vary within the country and among the audiences. These images about the country-of-origin, are deeply rooted and usually difficult to change in the target audience, since people tend to "pay attention to information that confirms their expectations" (Kotler and Gertner 2002, p. 251). Countries must assess their strengths, weaknesses, limitations and opportunities in comparison to other nations to determine where they can differentiate themselves, and then market to target audiences (Kotler and Gertner 2002).

Developing countries have less defined product-country images than developed countries (Nes and Bilkey 1993), however this idea is expanded upon by showing that consumers' opinions about a country's products and their opinion of the country are not necessarily the same (Papadopoulos et al.2000). Consumers were asked to rate a country based on variables such as "products overall", "willingness to buy", "ideal country" and "want closer ties with". While the countries' rankings confirmed Nes and Bilkey's findings, within the results from each country, a distinction existed depending on the variable. For example, German products and the country overall scored very highly (1st out of the 18 countries), however consumers ranked it 9th in the "ideal country" category. Canada was ranked 1st as an ideal country but 8th with regards to consumers willingness to buy products. This second example, where a country image is stronger than a product image, invites for further research into a country's specific place branding strategy. Countries that enjoy a positive image could use it to promote exports. By managing a place brand, a country can attempt to improve its economic results, however, countries and place branders must keep in mind that country images are not consistent across all sectors and that these images are not stagnant (Nagashima 1977; Lampert and Jaffe 1998; Jaffe and Nebenzahl 2001). 
Figure 4

\section{Simon Anholt's Nation Brand Hexagon}

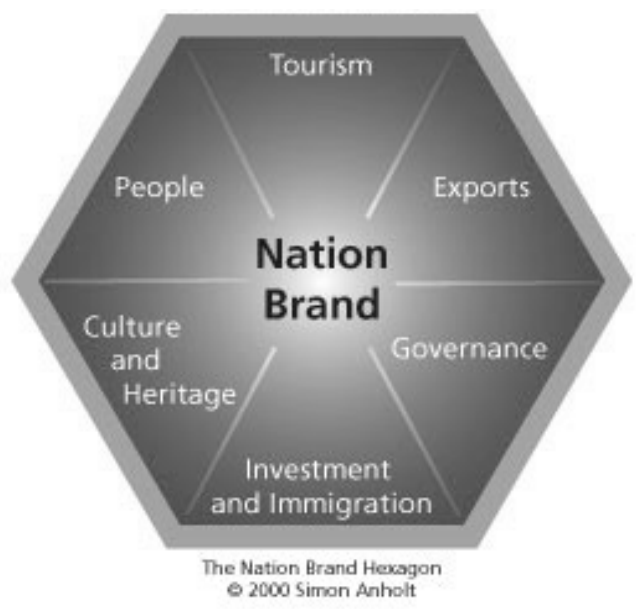

Source: Anholt-GfK Roper Nation Brands Index, GfK North America Custom Research, 2012.

Simon Anholt's place branding hexagon created a simple diagram (Figure 4) to show the integral parts of place branding (Anholt 2003; Anholt 2004). By outlining the six main opportunities that countries have to communicate their place brand to consumers, Anholt puts forth the idea that a nation brand is "the dominant channel of communication for national identity" (Anholt 2003, p. 139). Though Anholt has himself debated how big of an influence efforts to communicate a nation brand have made (Anholt 2008), it is clear that a consistent, harmonized, truthful and attractive brand is crucial to a successful nation brand program. By promoting a consistent place brand, it may be possible to create a coherent country image across sectors and help to improve international trade and relations.

The use of the $\mathrm{COO}$ effect, destination branding, and political marketing are all components of nation branding (Fan 2005). Nation branding is an intangible, emotional response to a country as a whole, whereas product-country image and the COO effect are linked to the product and form part of the consumers' purchase decision. Nation brands are dynamic associations that can be made up of the components in Figure 5. This dynamicism shows the changing nature of country images, country-of-origin perceptions, therefore and place brands. Nation branding attempts to affect how the customer perceives a country. A nation brand, unlike a product brand, is not easily controlled by the nation itself. A nation's brand identity is includenced by its citizens, their belifs, and their shared history (Jaworski and Fosher 2003). Consumer perceptions, according to Fan, are based on various factors such as personal experience with the country (travel, knowing a person from the country, knowing the language, etc), knowledge about the country, use of a product made from the country, media representation of the country and stereotypes. Therefore, customer-based experiences should controlled as much as possible in order to create a positive nation brand. 
Figure 5

\section{Associations that Contribute to a Nation Brand}

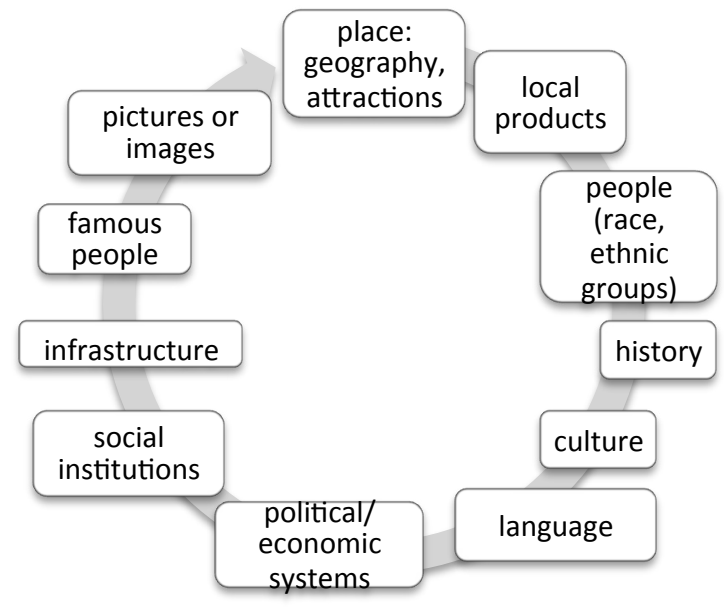

Source: Own elaboration, adapted from Fan (2005).

Yet another definition was proposed in 2010 to reconcile ongoing criticism of the term "nation branding" (Fan 2010). By first reviewing and compiling information about what scholars have claimed to be the purpose of nation branding, the author can clarify the difference between identity, image and reputation: "Identity is about self-perception...image refers to what is projected to the other, whereas reputation is the feedback received from the other" (Whetten and Mackey 2002, p. 400-402 quoted in Fan 2010). Fan then synthesizes and proposes a new definition for the task of nation branding: Nation branding is a process by which a nation's images can be created or altered, monitored, evaluated and proactively managed in order to enhance the country's reputation among a target international audience (Fan 2010, p. 101). Fan uses the term "nation image management" as an alternative to nation branding to more precisely portray the process and objective of organizing and controlling a nation brand, and to respond to disapproval of the term "branding".

As a developing field, place branding scholars frequently summarize recent ideas, findings, and topics of agreement in order to move forward in the field. It is established that place branding examines images, and "brand image is a concept that involves straying from observable reality into the world of perceptions" (Anholt 2010, p. 7). A brand is dependent on the product (or service) and is mainly controlled by marketing strategies within a company, whereas the brand image is created by the consumer and involves how a product is perceived (Figure 6). This becomes the basis of a new direction for place branding. As always, place branding has maintained the idea that a nation brand must able to stand up to its claims when tested by consumers. Nation branding research hasn't been able to prove that by promoting a national identity, logo, and slogan, a country can improve its exports, FDI and tourism. Place branding can be used as a starting point to organize efforts 
to improve the international image of a country, but to create a positive image in the minds of consumers, the main focus should be in developing quality products that can create positive consumer experiences which display the true value of the nation brand (Anholt 2010).

Figure 6

\section{Process of Country Branding}

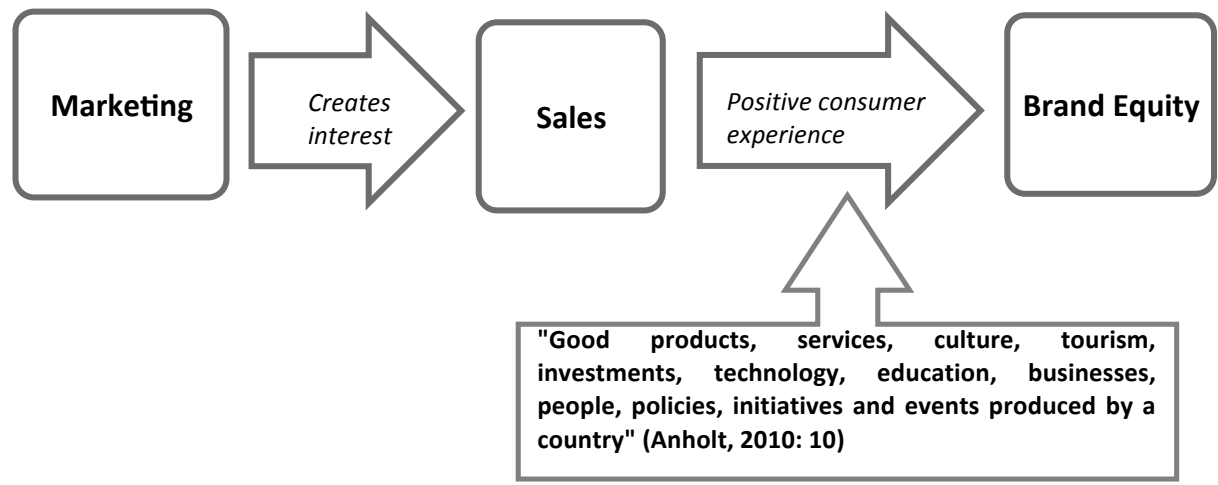

Source: Own elaboration; adapted from Anholt (2010).

The main focus of Anholt's 2010 commentary is to emphasize the need for real, valid efforts toward national development in order to present and market an image and reputation that truly stands up to its brand. Since 2010, there are few contributions from academics in the field of the nation brand who have tried a methodology to quantify the efforts. For example, a study on perception of South Africa -before and after the World Cup- showed that the perception of the country among Americans has improved (Fullerton and Holtzhausen 2012).

Table 3 relates chronologically the major studies on the construction and management of the brand country. The table reveals that the vast majority of the studies in the field of brand country are qualitative, scarce quantitative studies that can be used to measure or keep track of the efforts of a country brand campaign. Without the use of quantitative methods in this regard, it is difficult to assess how the evolution of the brand country changes the image of a country, as well as their perception and impact overseas.

Table 3

Main contributions on brand country (chronological order)

\begin{tabular}{|c|c|c|c|}
\hline Author & Year & Country (s) or area (s) analyzed (s) & Type of study \\
\hline Kotler et al. & 1993 & N/A* & Qualitative \\
\hline Olins & 1999 & N/A & Qualitative \\
\hline Girard & 1999 & N/A & Qualitative \\
\hline
\end{tabular}




\begin{tabular}{|c|c|c|c|}
\hline Papadopolos et al. & 2000 & $\begin{array}{c}\text { Germany, Australia, Canada, USA, Spain, } \\
\text { Japan, France, Greece, Holland, Hungary, } \\
\text { Indonesia, Mexico, Norway, Sweden }\end{array}$ & Quantitative \\
\hline Olins & 2001 & N/A & Qualitative \\
\hline Gilmore & 2002 & Spain & Qualitative \\
\hline Kotler and Gertner & 2002 & N/A & Qualitative \\
\hline $\begin{array}{c}\text { Jaworski, S.P. and } \\
\text { Fosher, D. }\end{array}$ & 2003 & N/A & Qualitative \\
\hline Anholt & 2003 & N/A & Qualitative \\
\hline Fan & 2005 & N/A & Qualitative \\
\hline Fan & 2010 & N/A & Qualitative \\
\hline Anholt & 2010 & N/A & \\
\hline
\end{tabular}

* The most qualitative studies do not include information specific to a country, hence "not applicable" (N/A) in the corresponding cells.

Source: Own elaboration.

\section{CONCLUSIONS}

In order to gain an understanding of how it a country brand is constructed and interpreted, it was necessary to first understand how country of origin affected the perception of a product or service, and in turn how this perception affected consumer decisions. In this literature review, first there was a revision of relevant literature and studies relating to the chosen topic. Country-of-origin studies have shown that consumers consider COO when evaluating a product (Schooler 1965). Informational cues about COO influence how the products are assessed, and may vary between consumers depending on gender, age, and education (Schooler 1971; Anderson and Cunningham 1972; Dornoff et al. 1974; Heslop and Wall 1985). Brand names give the consumers insight into the country-of-origin (without explicitly using a Made In label), and may be authentic or may be adopted so as to draw upon the positive qualities of another country's image (Wee et al. 1993; Papadopoulous et al. 1997). Finally, the dynamic quality of country images proves that nations can manage their country image in order to improve negative stereotypes and work to maintain positive images (Nagashima 1977; Han 1990; Lampert and Jaffe 1998; Jaffe and Nebenzahl 2001). Country-of-origin and its effect on the product is only one part of understanding the global marketplace; the audience is another important variable that will affect how a foreign product or service is perceived (Johannnson et al. 1985).

As a result of consumer-based research on the country-of-origin effect, place branding has been able to progress, building on findings about how consumers view foreign products, consumer relationships with national and foreign good and how they differ between consumer groups (stratified by age, education, income, etc.) (Bannister and Saunders 1978; Han 1989; Sammie et al. 2005). COO cues do not elicit the same reaction in consumers the same way across sectors, however, all sectors can benefit from efforts to manage a country image and promote positive qualities tied with $\mathrm{COO}$. As far as managerial implications, when promoting products, services, or a country brand abroad, is essential to understand the relationship between the export country and the consumer country, since historical 
relationships and consumer tendencies towards ethnocentrism may play a part in the receptiveness of the consumer. Nation branders must treat each new market individually, while still uniformly promoting the unique qualities of the nation brand.

Nation branding attempts to create a consistent image of a country in order to grant certain attributes to its products and services in the eyes of the consumer. By gaining an understanding of how country images are constructed, it's possible to use information about the $\mathrm{COO}$ effect and the consumer to identify how to manage each input to the nation brand. In Nation branding, as with product branding, the consumer experience is paramount, so understanding how consumers react to origin cues will help governments improve their nation branding programs to successfully manage their country's image abroad.

Any country that wants to participate in the global economy will have to manage its reputation abroad to increase competitiveness. As Michael Porter asserts, "national prosperity is created, not inherited" (Porter 1990, p. 73). Overall, country image management should aim to create a unique, concise and differentiating representation of a country. This image must be true to reality, both for the country's citizens and for the external audience. Managing a country brand should be the task of both the public and the private sector, as a positive image abroad improves imports, tourism, attraction of FDI and talent. Place branding is a dynamic field that is still in the process of identifying its objectives, methods, and definitions, but by understanding its foundation, scholars will be able to advance further in nation branding studies.

\section{REFERENCES}

Ahmed, Z.U., Johnson, J., Yang, X., Fatt, C.K., Teng, H.S. and Boon, L.C., 2004. Does country of origin matter for low involvement products? International Marketing Review, 21, 1,102- 120 .

Anderson, W.T. and Cunningham, W., 1972. The Socially Conscious Consumer. The Journal of Marketing. 36, 3, 23-31.

Anholt, S., 1998. Nation brands of the twenty first century. Journal of Brand Management, 5, 295-404.

Anholt, S., 2003. Brand New Justice: The Upside of Global Branding. Oxford: Butterworth-Heinemann.

Anholt, S., 2004. Branding Places and Nations. The Economist: Brands and Branding. Canada: The Economist Newspaper, Ltd., 213-226.

Anholt, S., 2008. Why Nation Branding does not Exist. Accessed 10 April 2015. http:// www.europaregina.eu/downloads/orangecontest/SimonAnholtNation Branding.pdf

Anholt, S., 2010. Definitions of Place Branding: Working Towards a Resolution. Place Branding and Public Diplomacy, 6, 1, 1-10.

Balabanis, G. and Diamantopoulos, A., 2004. Domestic Country Bias, Country-of-Origin Effects, and Consumer Ethnocentrism: A Multidimensional Unfolding Approach. Journal of the Academy of Marketing Science, 32, 1, 80-95.

Bannister, J.P. and Saunders, J.A., 1978. UK Consumers' Attitudes towards Imports: The Measurement of National Stereotype Image. European Journal of Marketing, 12, 8, 562-570. 
Bilkey, W.J. and Nes, E., 1982. Country-of-origin Effects on Product Evaluations. Journal of International Business Studies, Spring/Summer, 89-99.

Bruning, E.R., 1997. Country of origin, national loyalty and product choice: The case of international air travel. International Marketing Review, 14, 1, 59-74.

Chasin, J.B. and Jaffe, E.D., 1979. Industrial Buyer Attitudes Towards Goods Made in Eastern Europe. European Management Journal, 5, 3, 180-189.

Concha Velásquez, J., Gómez, E. and Valencia, P., 2011. El Efecto País de Origen Entre los Consumidores Colombianos: El Caso de un Producto de Consumo Masivo. Pensamiento y Gestión, 30, 150-164.

Dornoff, R., Tankersley, C. and White, G., 1974. Consumers' Perceptions of Imports. Akron Business and Economic Review. 5 (Summer 1974), 26-29.

Fan, Y., 2005. Branding the Nation: What is Being Branded? Journal of Vacation Marketing. 12, 1, 5-14.

Fan, Y., 2010. Branding the Nation, Towards a Better Understanding. Place Branding and Public Diplomacy, 6, 2, 97-103.

Fullerton, J., Kendrick, A. and Wallis, C., 2008. Brand Borat? Americans' reaction to a Kazakhstani place branding Campaign. Place Branding and Public Diplomacy. 4, 2, 159-168.

Fullerton, J. and Holtzhausen, D., 2012. Americans' attitudes toward South Africa: A study of country reputation and the 2010 FIFA World Cup. Place Branding and Public Diplomacy, 8, 4, 269-283.

Gilmore, F., 2002. A Country - Can it be Repositioned? Spain - The Success Story of Country Branding. Journal of Brand Management, 9, 4-5, 281-293.

Girard, M., 1999. States, Diplomacy and image making: What is new? Reflections on current British and French Experiences. Paper presented to Conference Image, State and International Relations, London School of Economics, 24 June 1999.

Hamzaoui, L. and Merunka, D., 2006. The impact of country of design and country of manufacture on consumer perceptions of bi-national products' quality: an empirical model based on the concept of fit. Journal of Consumer Marketing, 23, 3, 145-155.

Han, C.M., 1989. Country Image: Halo or Summary Construct? Journal of Marketing Research, 26, May, 222-229.

Han, C.M., 1990. Testing the Role of Country Image in Consumer Choice Behaviour. European Journal of Marketing, 24, 6, 24-39.

Heslop, L.A. and Wall, M., 1985. Differences between men and women in the country of origin product images. Administrative Sciences Association of Canada Proceedings, Montreal, Canada: 148-158.

Jaffe, E. and Nebenzahl, I.D., 2001. National Image and Competitive Advantage: The Theory and Practice of Country of Origin Effect. Frederisksberg: Copenhagen Business School.

Jaworski,S.P.and Fosher,D.(2003).National Brand Identity \& Its Effect on Corporate Brands: The Nation Brand Effect (NBE). The Multinational Business Review, 11(2), 99-108.

Johansson, J.K., Douglas, S.P. and Nonaka, I., 1985. Assessing the Impact of Countryof-origin on Product Evaluations: a New Methodological Perspective. Journal of Marketing Research, 22, 388-396. 
Kinra, N., 2006. The effect of country-of-origin on foreign brand names in the Indian market. Marketing Intelligence \& Planning, 24, 1, 15 - 30

Klein, J., 2002. Us Versus Them, or Us Versus Everyone? Delineating Consumer Aversion to Foreign Goods. Journal of International Business Studies, 33, 2, 345-363.

Kotler, P. and Gertner, D., 2002. Country as brand, product and beyond: A place marketing and brand management perspective. Journal of Brand Management, 9, 4-5, 249-261.

Kotler, P., Haider, D.H. and REIN, I., 1993. Marketing Places. New York: The Free Press.

Lampert, S. and Jaffe, E., 1998. A Dynamic Approach to Country-of-Origin Effect. European Journal of Marketing, 32, 1/2, 61-78.

Michaelis, M., Woisetschläger, D. M., Backhaus, C., \& Ahlert, D. (2008). The effects of country of origin and corporate reputation on initial trust: An experimental evaluation of the perception of Polish consumers. International Marketing Review, 25, 4, 404-422.

Nagashima, A., 1977. A comparative 'made in' product image survey among Japanese businessmen. Journal of Marketing, 41, 3, 95-100.

Nes, E. and Bilkey, W.J., 1993. A Multi-Cue Test of Country-of Origin Theory. In: Papadopoulos, N. and Heslop, L. (Eds.). Product Country Images: Impact and Role in International Marketing. New York: International Business Press. 179-196.

Olins, W., 1999. Trading Identities: Why countries and companies are taking each others' roles. London: The Foreign Policy Centre.

Olins, W., 2001. Branding the Nation - The Historical Context. Journal of Brand Management, 9, 4-5, 241-248.

O'Shaughnessy, J. and O'Shaughnessy, N., 2000. Treating the Nation as a Brand: Some Neglected Issues. Journal of Macromarketing, 20, 1, 56-64.

Papadopoulos, N. and Heslop, L.A., 1993. Product Country Images: Impact and Role in International Marketing. New York: International Business Press.

Papadopoulos, N., Jog, V., Heslop, L. and D'Souza, R., 1997. The Investment Climate in Canada: Foreign Investor Experiences and Perceptions in S. Preece 115 \& P. Woodcock (Eds.), Proceedings, Administrative Sciences Association of Canada, International Business Division, St. John's. 18, 37-47.

Papadopoulos, N., Heslop, L.A. and Ikon Research Group, 2000. A Cross-national and Longitudinal Study of Product-Country Images with a Focus on the US and Japan. Marketing Science Institute Report, 0-106.

Pappu, R., Quester, P. and Cooksey, R., 2007. Country Image and Consumer/Based Brand Equity: Relationships and Implications for International Marketing. Journal of International Business Studies. 38, 726-745.

Porter, M., 1990. The Competitive Advantage of Nations. Cambridge: Harvard Business Review.

Roth, K.P. and Diamantopoulos, A., 2009. Advancing the Country Image Construct. Journal of Business Research. 62, 7, 726-740.

Roth, M. and Romeo, J., 1992. Matching Product Category and Country Image Perceptions: A Framework for Managing Country-of-Origin Effects. Journal of International Business Studies. 23, 3, 477-497.

Samiee, S., Shimp, T. and Sharma, S., 2005. Brand origin recognition accuracy: its antecedents and consumers' cognitive limitations. Journal of International Business Studies, 36, 379-397. 
Schooler, R.D., 1965. Product Bias in Central American Common Market. Journal of Marketing Research. 2, 4, 394-397.

Schooler, R.D., 1971. Bias Phenomena Attendant to the Marketing of Foreign Goods in the US. Journal of International Business Studies. 2, 1, 71-81.

Sharma, S., Shimp, T. and Shin, J., 1995. Consumer Ethnocentrism: A Test of Antecedents and Moderators. Journal of the Academy of Marketing Science, 23, 1, 26-37.

Shimp, T. and Sharma, S., 1987. Consumer Ethnocentrism: Construction and Validation of the CETSCALE. Journal of Marketing Research, 24, 3, 280-289.

Stock, F., 2009a. Identity, Image and Brand: A Conceptual Framework. Place Branding and Public Diplomacy, 5, 2, 118-125.

Stock, F., 2009b. The Borat Effect. Place Branding and Public Diplomacy, 5, 3, 180-191.

Thakor, M.V. and Kohli, C.S., 1996. Brand origin: conceptualization and review. Journal of Consumer Marketing, 13, 3, 27-42.

Usunier, J.C. and Cestre, G., 2007. Product Ethnicity: Revisiting the Match Between Products and Countries. Journal of International Marketing, 15, 3, 32-72.

Van Ham, P., 2001. The Rise of the Brand State: The Postmodern Politics of Image and Reputation. Foreign Affairs. 80, 5, 2-6.

Van Ham, P., 2008. Place Branding: The State of the Art. The Annals of the American Academy of Political and Social Science. I616, 1, 126-149.

Wee, C., Lim, D. and Tan, G., 1993. The Image of Countries as Locations for Investment. In: Papadopoulos, N. and Heslop, L. (eds.): Product Country Image: Impact and Role in International Marketing. Binghampton: International Business Press, 311-338.

Whetten, D.A. and Mackey, A., 2002. A Social Actor Conception of Organizational Identity and its Implications for the Study Of Organizational Reputation. Business \& Society. 41, 4, 393-414.

White, C., 2012. Brands and National Image: An Exploration of Inverse Country-Of-Origin Effect. Place Branding and Public Diplomacy. 8, 2, 110-118. 